MYKOLO ROMERO
UNIVERSTIEAS

\title{
ANALOGOUS SIMULATION OF NATION-SCALE MACROECONOMIC DECISIONS (IS THE BALTIC ABLE TO ARRANGE THE UEFA EURO 2024?)
}

\author{
Viktoras Justickis \\ Mykolas Romeris University, Faculty of Social Policy, \\ Institute of Psychology \\ Ateities 20, LT-08303, Vilnius, Lithuania \\ E-mail: justickv@takas.lt \\ Telephone: $(+370) 2714620$ \\ Nikolajus Markevičius
}

Mykolas Romeris University, Faculty of Economics and Finance Management, Institute of Economics and Business

Ateities 20, LT-08303, Vilnius, Lithuania

Telephone: $(+370) 2714547$

E-mail: bochakolita@gmail.com

Received on 24 May, 2012; accepted on 20 June, 2013

doi:10.13165/SMS-13-5-3-07

\begin{abstract}
Taking of the nation-scale (macroeconomic) decisions is one of the most challenging problems in the modern economy. The main problem is unimaginable complexity of modern national economies. Every nation-scale decision influences multiple its sides, innumerable factors, events, consequences, interconnections. Therefore, the consequences of every such decision are very multisided, conflicting, unanticipated. Beside the intended outcomes, a great deal of unintended, unforeseen, harmful, contra-productive ones caused.

This inability to foresee exact outcomes of macro-decisions is caused, first of all, by our inability to model and simulate national economy. Despite all brilliant achievements and quick progress in the modern economic modeling, we are still very far from building models


including many thousands of factors acting in any national economy and thus, we are unable to simulate its reaction to our decisions.

This, in turn, brings the modern day situation, when even the most important, nationalscale economic decisions are still taken politically, in the most intuitive, subjective, speculative and, thus, deficient way.

All this brings the urgent necessity to find alternative methods of macroeconomic modeling, able at least to some degree simulate reactions of the national economy to great macroeconomic decision and this way to improve the current intuitive and political decision taking.

In this paper one of such ways- analogous simulation is considered.

The general idea of this approach is to study how the supposed national - scale decision worked in countries with economies that are as much as possible similar to our, especially in aspects, most relevant to decision under consideration.

The belief that such a similar economy can be used as a model is based upon three presumptions:

1. "The similarity causes similarity" presumption, supposing that the more observable similarities exist between two economies the more also unobservable ones they do have.

2. "Decision related similarity" presumption, saying that similarities of directly affected sides of economy are of especial salience when using another economy as a model to forecast effects of some decision.

3. "The common core" presumption, saying that the affinity between two similar economies is still more enlarged (multiplied) by sharing all traits that are basic for all the modern market economy.

4. "The shared space" presumption. This presumption supposes that affinity between two similar economies is still more enlarged by sharing the common (e.g., European) geographic, cultural, economic, politic space and sharing all conditions specific for this space.

All this produces multisided, thousands of different factors including similarity between such economies. In this situation we can consider one economy and effects of some action in it as a model, able to forecast similar effects in the other one.

As illustration, the highly challenging national-scale decision on organization of UEFA Euro 2024 in the Baltic is analyzed. Portugal (that already has arranged the UEFA Euro) and its national economy were selected as a highly suitable analogue model for Baltic countries and for probable success UEFA Euro 2024 in the Baltic.

Keywords: nation-scale, macroeconomic decisions, macroeconomic modeling, UEFA EURO 2024, Baltic countries, Finland, football, the free market, state regulation.

\section{Introduction}

\section{Problem}

Modern national economy is an object of unbelievable complexity, involving thousands of interconnected and interacting factors, influences and developments. Therefore, any macroeconomical impact on it is quite similar to an attempt to fix the 
highly sophisticated mechanism by axe and is fraught with unexpected complications and contra-productive consequences.

Our ability to model a national economic system and to simulate national scale decision is the most challenging problem of the modern economy. On the one side, it is widely recognized that economy needs regulation and, therefore, important national scale decision searching to change it must be taken. However, on the other side, there are many important reasons not to do this . The most important is our obvious inability to foresee real effects of our decisions. The history of the modern economy is full of examples showing that even decisions that have been very thoroughly prepared, widely discussed and examined by the best experts can be highly unsuccessful and bring frustration and economic losses instead of intended positive results.

This is especially true and sensitive when a decision under consideration is not only nation scale, but also risky, intended to bring great gains for nation, but, instead, brings huge losses. Therefore, talking of the salient nation-scale (macroeconomic) decisions is one of the most challenging problems of the modern economy.

The main problem in taking such decisions is unimaginable complexity of modern economy. Every nation-scale decision influences innumerable sides, factors, events, consequences, interconnections.

Joint complexity of all these factors are to be included in the model but there is no technical computer resource able to process all, we are remain unable to develop models including many thousands of multisidedness Therefore, even the most important, nation-scale economic decisions are taken on political basis, in the most intuitive, subjective, speculative and, thus, deficient way.

All this points to the necessity to find alternative methods of macroeconomic modeling, able to model a national economy and to simulate its reaction to some macroeconomic decision.

In this paper one of such methods - analogous simulation is considered. This method is based upon research on how the nation-scale decisions acted in countries with economy in all most important aspects similar to Lithuanian economy.

\section{State of art}

The concept "analogous" is widely used in economy. However, the idea of using similar economies as analogous model to simulate nation-scale decisions is, to our knowledge set forth and discussed for the first time. However, analogous models are widely used simulating different human activities, especially in technology, mechanics, etc $^{1},{ }^{2}, 3$. Analogous decisions are also used in economy solving some rather local and specific tasks. In the attempt to exemplify the current situation, an informational search in EBSCO and other data banks has been carried out. The key words used were:

1 Poole, I. Cellular Communications Explained: From Basics to 3G. Oxford: Newness, 2006

2 Analogue systems. Cornwall, 2012 [interactive]. [ Retrieved 5 December, 2012]. <http://www.analoguesystems.co.uk/index 2.htm>.

3 Sivilevičius, H. Modelling the interaction of transport system elements. Transport (16484142). 2011, Mar2011, Vol. 26 Issue 1, p.20-34. 
"national economic" and "modeling" or "simulation" or "imitation", "analogues". The information search brought 648 publications containing these concepts. All of them were focused on the use of some kinds of mathematical models for simulation (imitation) of some national economy or its parts. Only five positions used the concept "analogy", no one dealt with any analogs of any national economy. All this supports our conclusion that the analogous modeling of the kind proposed in this report was neither suggested nor studied before.

\section{Structure of the article}

The first chapter discusses the idea and presumptions behind the analogous modeling of the multisided consequences of a nation-scale decisions (and following actions) for national economy. The second chapter "The costs of the UEFA EURO in 2008 and 2012" discusses an example of such a nation-scale decision. It is the decision on arrangement of Euro UEFA in a country with a weaker economy. Using the example of Ukraine, the challenging and risky nature of this decision is shown. It is demonstrated how great is the threat that, instead, of intended nation-scale gains such decision can bring innumerable nation-scale losses.

The third chapter describes how the analogue modeling of the same decision can be used. The probable consequences of the decision to carry out the UEFA EURO 2024 in the Baltics and demonstrates feasibility and the economic perspective of such a decision.

The fourth chapter provides an attempt to specify economic parameters of such decision and to calculate its costs and profits.

\section{Nature and Presumptions of the Analogous Modeling of a Nation - Scale Decision}

Analogy is an inference or an argument from one particular to another particular, as opposed to deduction, induction, and abduction, where at least one of the premises or the conclusion is general. The word analogy can also refer to the relation between the source and the target themselves, which is often, though not necessarily, a similarity, as in the biological concept of analogy ${ }^{4},{ }^{6},{ }^{6}$. The general idea of the approach proposed in this report is to study how the nation-scale decision in one economy(one particular) has worked in countries with economies that are as similar to the one under consideration as could be found.

4 Sowa, J.; Arun, K. Analogical reasoning. Conceptual Structures for Knowledge Creation and Communication, Proceedings of ICCS 2003. Berlin: Springer-Verlag, 2003 [interactive]. [Retrieved 7 December, 2012]. <http://www.jfsowa.com/pubs/analog.htm., pp. 16-36.>

5 Itkonen, E. Analogy as Structure and Process. Amsterdam/Philadelphia: John Benjamins Publishing Company, 2005.

6 Coelho, I. Analogy. ACPI Encyclopedia of Philosophy. Bangalore: ATC. 1:64-68. Ed. Johnson J. Puthenpurackal, 2010. 
As a general similarity we will address the number and degree of specific similarities in economies of the two countries.

1. It is supposed (as an ideal case) that if two economies are similar in all their traits, then the identical impact upon their economies will cause identical consequences. This means that one of these two economies can be seen as an ideal model for discovering all consequences brought by some economic decision also in the other one.

2. It is also supposed that the more similar are economies of the two countries, the more similar will be effects of such identical decisions.

Considering the nature of similarities of two or more economies, four basic assumptions are made:

Assumption 1. The similarity causes similarity assumption. It assumes that the more observable similarities are between two economies the more unobservable ones they do have. This assumption is based upon the idea that similarity of an economical trait tends to bring similarity also in their effects upon closely related unobservable traits and this provides us with the basis to assume their similarity.

Assumption 2. Decision related similarity assumption.

Each nation - scale decision, first of all, brings changes into some part of the national economy. Next, this changeevokes the "chain reaction" of the following changes in the rest of the economy. Because of this the change of the part of the national economy immediately affected by nation-scale decision is the most important and takes a role of an "engine" for the following changes, the similarities of these directly affected parts of the economy are of especial value when using another economy as a model to forecast effects of some decision.

Assumption 3. The common core assumption.

It says that the affinity between two similar economies is tighter (multiplied) through sharing all traits that are basic for all modern national economies (and, therefore, described in any modern manual of macroeconomics). There is a good ground to believe that effects of similar impacts to two national economies are similar for the simple reason that both are modern market economies. This means that they are based upon the same principles and their function and development follows the same regularities.

Assumption 4. The shared space assumption.

This assumption supposes that the affinity between two similar economies is still more enlarged by sharing the common economical space (e.g., European one). The reason for this is that economies sharing the same geographic, cultural, economic, political space share all conditions specific for this space.

The joint effect of all these assumptions for two in many respects similar economies (particularly the decision-related similarities - (see assumption 2) is that their similarities tends to be intensified by their functioning and development (assumption 3 ) and by shared economic, geographic and other spaces (assumption 4).

This provides the ground for the most important statement that observable similarities between two economies should not be seen as superficial or isolated ones. In fact, they tend to be in close interconnection with the multisided affinity of two 
economies. All this produces multifarious, thousands of different factors embracing similarity between such economies.

In this situation we can consider one economy and effects of some action in it as a model, able to forecast similar effects in the other one. In the next chapter an example of the highly challenging national-scale decision on organization of UEFA Euro 2024 in the Baltics is analyzed. Disastrous possible consequences of such decision for a national economy will be illustrated.

\section{The Costs of the UEFA EURO in 2008 and 2012}

The infrastructure of sports facilities in Eastern Europe is in its richness and technical equipment far behind Western Europe infrastructure. Therefore, the construction of such facilities in the new EU countries will lead to the growth of the aggregate supply of goods and services, and will lead to, at least, a short-term economic recovery. Moreover, the complex objects as the infrastructure in general cannot be built and completed only by the countries in which they are constructed. This fact increases the aggregate demand for goods and services in the old EU member states, that also stimulates an output of a part of their economy from recession. This suggests, the idea, that thanks to the particular large-scale sports events in the relatively weaker regions of Europe, the economies will put in place the infrastructure of required standard, and that approach is one of the ways to pull out the entire EU economy from the crisis.

The basis for the football infrastructure is the material presenceof football stadiums. Following the results of 2009 poll there were 96 stadiums with seating capacity over 30000 , including 24 with an artificial covering in Europe. An average term of maintenance for stadiums is 47 years; the requirement is that there would lapse no more than 7 years ${ }^{7}$ since last renovation.

According to the decision of UEFA Executive Committee to increase the team quantity in a final stage of tournament since $2016-24$, football matches to be played on 9 stadiums and 3 spare stadiums have to be available. The capacity of two stadiums should be over 50 thousand seats; of three stadiums over 40 thousand and of four over 30 thousand seats.

In average term of stadiums maintenance is long and for economically developed countries issues of renovation and construction of new stadiums come up most. So the size of investments into stadiums is estimated for EURO 2016 at $1,7^{8}$ bn euros, and for the World Cup 2018 at of $3,82^{9}$ bn US dollars or about 3,2 bn euros.

7 UEFA Club Licensing and Financial Fair Play regulations. Nyon, 2009 [interactive]. [Retrieved 23 August, 2012]. <http:/www.uefa.com/uefa/footballfirst/protectingthegame/clublicensing/index.html>.

8 La France accueillera le championnat d'Europe de football en 2016. La France a remporté l'Euro 2016. Moscou, 2011 [interactive]. [Retrieved 3 August, 2012]. <http://www.ambafrance-ru.org/La-France-accueillera-le>

92018 FIFA World CUP. Bid Evaluation Report: Russia. Zurich, 2010 [interactive]. [Retrieved 24 August, 2012]. <www.fifa.com/mm/document/.../b5ruse.pdf $>$. 
For less developed countries issues relatedto the general transport infrastructure come as th emost urgent. However, investment in stadiums in economically less advanced countries is as high as in the highly developed countries. Therefore, costs of the EURO 2016 organization in such countries as Portugal,Poland,Ukraine exceed investments in countries as for example Belgium, Holland or Austria andSwitzerland. So for example, expenditures on EURO 2008 came up to about $791 \mathrm{mln}$.euros, including Switzerland $180^{10} \mathrm{mln}$.CHF or about $150 \mathrm{mln}$. euros and Austria $640,8^{11} \mathrm{mln}$. euros.

The total costs in Poland and Ukraine exceeded costs in Austria andSwitzerland 48 times and totalled according to the Ministry of Tourism and Sport of Poland ${ }^{12}$ and the Ministry of Infrastructure of Ukraine ${ }^{13}$ to 38,2 bn euros. From data given in Table 1 follows, that the main share of cumulative expenditures over $80 \%$ was directed on objects of transport infrastructure and only about $7 \%$ for sport venues. But even the amount directed for the sports infrastructure was so large, about 2,6 bn euros, that it could undermine the credibility of the smaller countries in the solvency of the sporting ambitions of the organizing next EURO event.

Table 1. Structure of investment spending related to the EURO $2012^{14}$

\begin{tabular}{|c|c|c|c|}
\hline Investments & $\begin{array}{l}\text { Poland PLN* bn / } \\
\text { EUR bn / \% }\end{array}$ & $\begin{array}{c}\text { Ukraine UAH* bn / } \\
\text { EUR bn / \% }\end{array}$ & $\begin{array}{l}\text { Poland + Ukraine } \\
\text { EUR bn } / \%\end{array}$ \\
\hline $\begin{array}{l}\text { Transport: } \\
\text { airports } \\
\text { roads } \\
\text { railroads } \\
\text { public trans- } \\
\text { port } \\
\text { Sport venues } \\
\text { Hotels } \\
\text { Others }\end{array}$ & $\begin{array}{c}94 / 23,5 / 85,4 \% \\
4 / 1,0 / 3,6 \% \\
63 / 15,8 / 57,3 \% \\
17 / 4,2 / 15,4 \% \\
10 / 2,5 / 9,1 \% \\
5 / 1,25 / 4,5 \% \\
5 / 1,25 / 4,5 \% \\
6 / 1,5 / 5,6 \%\end{array}$ & $\begin{array}{c}79 / 7,9 / 73,8 \% \\
22 / 2,2 / 20,6 \% \\
32 / 3,2 / 29,9 \% \\
19 / 1,9 / 17,8 \% \\
6 / 0,6 / 5,5 \% \\
13 / 1,3 / 12,1 \% \\
10 / 1,0 / 9,3 \% \\
5 / 0,5 / 4,8 \%\end{array}$ & $\begin{array}{rr}31,4 / 82,2 \% & 3,2 / 8,4 \% \\
& 19,0 / 49,7 \% \\
& 6,1 / 16,0 \% \\
& 3,1 / 8,1 \% \\
2,55 / 6,7 \% & \\
2,25 / 5,9 \% & \\
2,0 / 5,2 \% & \end{array}$ \\
\hline Total & $\begin{array}{l}110 \text { PLN bn / } \\
27,50 \text { EUR bn }\end{array}$ & $\begin{array}{l}107 \text { UAH bn/ } \\
10,7 \text { EUR bn }\end{array}$ & 38,2 EUR bn \\
\hline
\end{tabular}

* For simplicity of calculation was used the euro exchange rate to zloty $1: 4$ and to hryvnia 1:10; to $\$-1: 1,2$.

10 Aeschbacher, R. Euro 2008. Hohe Gewinne für die Uefa und Kosten für den Staat? Das Schweizer Parlament. Bern, 2008 [interactive]. [Retrieved 5 September, 2012]. <http://www.parlament.ch/d/suche/seiten/ geschaefte.aspx?gesch_id=20083442>.

11 Info-Guide of the Austrian Federal Chancellery. Sports Division and SpEA SportsEconAustria.. Vienna, 2008. Issue No.3/May 2008 [interactive]. [Retrieved 5 September, 2012]. <http://www.esce.at/speafile/080523\%20UEFA\%20EURO \%202008\%20Datenvademecum\%20EN.pdf $>$.

12 Masterplan of Ministry of Sport and Tourism, State program for EURO 2012 preparation. Warsaw, 2012 [interactive]. [Retrieved 3 September, 2012]. <http://www.msport.gov.pl/przedsiewziecia-euro-2012>

13 Strategy development of a transport industry of Ukraine, preparation to the EURO-2012, investment potential. . Kyiv, 2010. [interactive] [Retrieved 29 August, 2012] from <http://mtu.gov.ua/article/show/article_id/16568/highlight/euro+2012>

14 Composed by autors. 


\section{Similarities and Differences of Portugal with the Baltic Countries and Finland, Based on the Football Contex}

In the context of EURO 2024 orginizing ambition and huge expenses for implementing this ambition by Poland and Ukraine, Portugal expereince, with rather modest GDP, in undertaking EURO 2004 causes enviable aspiration to repeat success of this country on the organization of the subsequent EURO events. In this connection, the similarity of Portugal, the Baltic countries and Finland position draws attention. This similarity begins with geography: the furthemost borders of EU in the West and in the East; approximate numbers of population and GDP are of comparable size. Portugal undertaking EURO 2004 arrangements faced the same challenges that may prove to come ahead of the Baltic States and Finland, if UEFA will grant them the priviledgeto host EURO 2024. As Finland on all macroeconomic parameters essentially overtakes 3 Baltic countries, we will exclude it from our research, except for an assessment of investments into the construction of stadiums. As can be seen from Table 2 Baltic States and Finland in 2011 were ahead of the host country of EURO 2004 in GDP. The Baltic States since the end of 2008 and Portugal since the beginning of 2001 were under the influence of an economic crisis. Unemployment and inflation that caused a big budgetary deficit sharply jumped up. However, due to the right of the third largest sporting event of the world, for a host country 2004 opened up significant economic stimuli. Despite considerable investment, estimated at about 4 bn euros, including 600 mil.euros of investment in stadiums, Portugal, thanks to the good organization of Euro 2004, could significantly enhance its image and increase its visibility and identification worldwide. That provided long-run financial flows to Portugal economy.

Table 2. Population and GDP in the Baltic States and Finland in comparison to Portugal in $2011^{15}$

\begin{tabular}{|l|c|c|c|}
\hline \multicolumn{1}{|c|}{ Country } & Population Mil. & \$US bn nominal & \$US bn PPP \\
\hline Portugal & 10,4 & 239 & 248 \\
\hline Finnland/SF & 5,4 & 267 & 196 \\
\hline Estonia/EE & 1,3 & 22 & 27 \\
\hline Latvia/LV & 2,1 & 28 & 34 \\
\hline Lithuania/LT & 3,0 & 43 & 61 \\
\hline SF+EE+LV+LT & 11,8 & 360 & 318 \\
\hline SF+EE+LV+LT to Portugal in $\%$ & $113 \%$ & $150 \%$ & $128 \%$ \\
\hline
\end{tabular}

One of the major differences between Portugal and the Baltic States and Finland is the very popularity of football. Portugal is highly rated in a big group of National Federations and the attendance of its championships is much higher, which affects the

15 IMF World Economic Outlook (WEO). (2012) [interactive]. [Retrieved 5September, 2012]. < http://www. imf.org/external/pubs/ft/weo/2012/01/index.htm.> Composed by autors. 
profitability of the stadiums. On the other hand it can be argued that the improvement of football technical basis will cause an influx of young players who definitely strengthen and make more attractive Baltic National Football Leagues. Perhaps, it is time to organize a single football league of the Baltic countries or even united national teams to raise their ranking in the UEFA classification.

\section{An Attempt to Calculate Expenditures on EURO 2024}

In calculating the expenditures on EURO 2024, we started from the data on EURO 2012, as transport, sports and hotel infrastructure in the above countries are very similar. As we have noted, Finland is eliminated from the above calculations on infrastructure spending, with the exception of the spendings on theconstruction of stadiums. We proceed from the fact that Finnish investments in infrastructure can make a comparable amount of the EURO 2008 organizers and without sports infrastructure should not to exceed 300-500 mil.euros, raising the general investments of EURO 2024 given in Table 3, no more than for 3-5 \%. According to "Worldstadiums Europe"16 there is only one stadium in the Baltic region, in Finland over 40.000 seats, which meets the requirements for the UEFA EURO. This means that another 11 stadiums should be raised. By our calculations, proceeding from the analysis of expenses for EURO 2012, for a construction or renovation of 11-12 stadiums it could be required from 2,1 to 2,3 billion euros. In Lithuania the construction of the national stadium with a capacity of 30-35 thousand has long been debated. We believe that the construction of a still bigger stadium which would contain 50.000 seats could be taken into consideration. It also appears that there would be no objections on construction of national stadiums in Riga and Tallinn as the Reform Party Fraction in Tallinn suggested to make the utmost that Estonia became host of the European Championship 2024 ${ }^{17}$. For example, in Portugal, in Lisbon (560 thousand inhabitants) and Porto (270 thousand

inhabitants) two stadiums were constructed in each city of the capacity of 65.000 and $52.000-52.000$ and 30.000 spectators respectively ${ }^{18}$.

For making EURO 2024 happen it is necessary to improve transport infrastructure fundamentally. By our calculations $200 \mathrm{~km}$ of road in Estonia, $200 \mathrm{~km}$ in Latvia and about $240 \mathrm{~km}$ in Lithuania have to be added. We considered only a route of "Via Baltica", disregarding upgrade of roads in East direction. Polish data ${ }^{19},{ }^{20}$ on the cost

16 Stadiums in Europe. [interactive].[ Retrieved 6 September, 2012] from <http://www.worldstadiums.com/ europe/maps/europe.shtml>

17 Reformisty predlozhili provesty $v$ Estonii EVRO-2024. [Reformists suggested to carry out in Estonia EURO2024.] .Tallinn, 2010. [interactive]. [Retrieved 20 August, 2012] from <http://rus.postimees.ee/337081/ reformisty-predlozhili-provesti-v-jestonii-evro-2024/>

18 Portugalija - samaja zapadnaja strana Evropy. [Portugal - the most western country of Europe.] Moscow, 2007 [interactive]. [Retrieved 7 September, 2012] . <http://www.c.weare1.info/europe-portugal.html >.

19 Polskie autostrady najdrozsze w Europie. Warszawa, 2012 [interactive]. [Retrieved 10 September, 2012]. $<$ http://www.drogi.inzynieria.com/cat/19/art/22034/analiza-kosztow-budowy-autostrad-w-europiecentralnej.html>.

20 Polskie autostrady najdroższe w Europie. Warszawa, 2005 [interactive]. [Retrieved 10 September, 2012]. $<$ www.bankier.pl/wiadomosc/Polskie-autostrady-najdrozsze-w-Europie-1248251.html>. 
of $1 \mathrm{~km}$ of highways in Poland in preparation for EURO 2012 averaged 6,1 mil.euros, and in Ukraine up 5 million US dollars ${ }^{21}$. For our calculations we counted 5 mil.euros per $1 \mathrm{~km}$ cost.

Table 3. Calculations and structure of possible investment spending related to the EURO $2024^{22}$

\begin{tabular}{|l|lr|}
\hline & \multicolumn{2}{|c|}{ Finnland, Estonia, Latvia, Lithuania EUR bn / \% } \\
\hline Transport: & $4,5-6,7 / 55,6 \%-58,3 \%$ & $0,2-0,8 / 2,5 \%-7,0 \%$ \\
$\begin{array}{r}\text { airports } \\
\text { roads } \\
\text { railroads }\end{array}$ & $3,0-3,5 / 37,0 \%-30,4 \%$ \\
public transport & & $0,8-1,8 / 9,9 \%-15,7 \%$ \\
Sport venues & $2,1-2,3 / 25,9 \%-20,0 \%$ & $0,5-0,6 / 6,2 \%-5,2 \%$ \\
Hotels & $1,0-1,5 / 12,3 \%-13,0 \%$ & \\
Others & $0,5-1,0 / 6,2 \%-8,7 \%$ & \\
Total & $8,1-11,5$ EUR bn \\
\hline
\end{tabular}

This would also include the goodwill of Poland on building highways or motorways from the city Ostrów Mazowiecka to the border with Lithuania. This segment has a length of about $200 \mathrm{~km}$. Moreover, if the part of road S8 Warsaw-Bialystok, is included in plan of Generalna Dyrekcja Dróg Krajowych i Autostrad (GDDKiA), so a modernization of the motorway S61 Ostrów Mazowiecka-Lomza-Suwalki-Poland's border isn't in this plan at the moment ${ }^{23},{ }^{24}$. The marked segment of the highway to the Lithuanian boundary also can cost to $1,2-1,3$ bn euros.

Other infrastructure facilities include airports, high-speed railway and urban transport. The airports shall provide output up to 10-12 thousand passengers within 10 hours before and after match completions. For comparison we can list an investment into the airport of Lviv (758 thousand inhabitants ) it is about 150 million euros.

High-speed railway connecting the host cities could partially overlap the project «Rail Baltica». It is necessary to mention that the cost of the similar project implemented by Ukraine was about 173 million euros for new high-speed Hyundai railway trains linked the host cities - Kiev, Lviv, Kharkiv and Donetsk ${ }^{25}$. For example,other schedulable

21 Kolesnikov nazval stoimost kilometra ukrainskikh dorog. [Kolesnikov called the cost of kilometer of the Ukrainian roads.] Kyiv, 2012 [interactive]. [Retrieved 5 September, 2012]. <http://gazeta.ua/ru/articles/ business/_kolesnikov-nazval-stoimost-kilometra-ukrainskih-dorog/437284>.

22 Calculated and composed by autors.

23 Polska budowa dróg w latach 2007-2015. Warszawa, 2010 [interactive]. [Retrieved 28 August, 2012]. <http://www.transport.gov.pl/files/0/1793483/projektProgramuBudowyDrgKrajowychnalata20112015. pdf>.

24 Sprawozdanie z realizacji przedsięwzięć Euro 2012 oraz z wykonanych działań, dotyczacych realizacji przygotowań Polski do finałowego turnieju Mistrzostw Europy w Piłce Nożnej UEFA EURO 2012 TM (marzec 2011 r. - styczeń 2012 r.). Warszawa, 2012. [interactive]. [ Retrieved 7 September , 2012]. <http:// sejmometr.pl/projekt/445,dokument/46156,druk-nr-291>.

25 New high-speed Hyundai railway trains linked the host cities-Kiev, Lviv, Kharkiv and Donetsk. 24.05.2012. Vienna, 2012. [interactive]. [Retrieved 1 August, 2012]. <http://diepresse.com/>. 
expenses could be compared to investments into urban transport infrastructure of Lviv - about $140 \mathrm{mln}$. euros, Donetsk (about 1,0 mln. people) - $43 \mathrm{mln}$. euros and Kharkiv (about 1,5 mln. people) - $34 \mathrm{mln}$. euros $^{26}$. Total cost of EURO 2024 in the Baltic countries could range from 8,1 to 11,5 bn euros. Starting investment in 2014 , the amount will make from 0,8 to 1,1 bn eurosper annumin 3 countries within 10 years or $300 \mathrm{mln}$.euros per annumin one country.

Of course, the biggest challenge is the question of where to get the money. Most of the funding for the projects 2012 came from central and local budgets. However, a large part $-31 \%$, was financed by the $\mathrm{EU}^{27}$ and $40 \%$ of the costs through private investment ${ }^{28}$.

Another challenge is the desire of other countries to host EURO 202029-2024 The rival countries are: the Netherlands; Turkey; Italy andSlovenia; the Czech Republic and Slovakia; Romania,Bulgaria and Hungary; Scotland,Ireland and Wales; Bosnia, Herzogovina, Croatia, and Serbia; Finland, Sweden,Norway and Denmark.

\section{Conclusions and Suggestions}

1. Taking nation-scale (macroeconomic) decisions is one of the most challenging problems in the modern economy, caused by unimaginable complexity of modern national economies and inability of the modern econometrics to develop mathematical models able to imitate processes in the national economy caused by impacts upon it.

2. The analogous simulation of a national economy by the similar one can be considered as a possible way for solution of this problem.

3. The belief that such a similar economy can be used as a model can be based upon four assumptions: 1). The similarity causes similarity assumption, supposing that the more observable similarities exist between two economies the more unobservable similarities they do have; 2). Decision related similarity assumption, saying that similarities of directly affected sides of economy are of especial value when using another economy as a model to forecast effects of some decisions; 3). The common core assumption, saying that the affinity between two similar economies is boosted (multiplied) by sharing all traits that are basic for all the modern market economies; 4). The shared space assumption. This assumption supposes that affinity between two

26 U Ukraine stroitelstvo $1 \mathrm{~km}$ dorogi obkhoditsja $v 5 \$ \mathrm{mln}$. [In Ukraine construction of $1 \mathrm{~km}$. roads costs $\$ 5$ million]. Kharkiv, 2011. [interactive]. [Retrieved 7 September, 2012]. <http://stroyobzor.ua/news/75338>.

27 Regional Economic Outlook. May 2011. Wasington D. C., 2011 [interactive]. [Retrieved 5 September, 2012]. <http://www.imf.org/external/country/ukr/index.html>.

28 The annual macro-economic database of the European Commission's Directorate General for Economic and Financial for non-EU countries. Brussels, 2012 [interactive]. [Retrieved 3 September, 2012]. <http:// ec.europa.eu/economy_finance/db_indicators/ameco/index_en.htm>.

29 UEFA_Euro_2020_bids. San Francisco, 2012 [interactive]. [Retrieved 2 August, 2012]. <http:// en.wikipedia.org/wiki/UEFA_Euro_2020 bids>.

30 Chempionat Evropy po futbolu 2024. [European Football Championship 2024] San Francisco, 2012. [interactive]. [Retrieved September 6, 2012]. <http://ru.wikipedia.org/wiki/Чемпионат_Европы_по_ футболу_2024>. 
similar economies is enhanced by sharing the common (e.g., European) geographic, cultural, economic, political space and sharing all the conditions specific to this space.

4. All this enables us to use similar economy as a model to forecast the success and consequences of a nation-scale decision

5. In physics there is a conservation law of potentials for separate bodies. They are going to flow in contact if bodies are at different potentials - from largest to smallest. Such potential in economy is the infrastructure in its various forms: transport, hotels, sports, tourism, industry, innovation, higher education, research, etc. Potential spill-over function is the freedom of movement within this infrastructure. This was mentioned in relation to trade as early as A.Smith, D.Ricardo, and in relation to innovation it was mentioned by J.Schumpeter. Therefore, the good infrastructure in each area is a basis of successful equivalent access to infrastructural products. The lack of such infrastructure creates an overflowing of potentials from bigger to smaller. Financial resources, however, flow in the opposite direction. In this sense, state intervention in the economy as a promoter of equality infrastructure in comparison with developed countries, in some areas at least, is in our understanding, the keynesianism help to the free market.

6. Hence the EURO 2024 is one of the ways to create a competitive infrastructure in the field of sports, tourism, hotel business, transport, urban development, which will provide long-term financial backflows, as the rent on the established infrastructure.

7. The comparative study leads to the conclusion that the Baltic States \& Finland are able to organize and finance the EURO 2024. The main dilemma is in confidence of the Baltic States of overcoming economic doubts in organizing such a big event as EURO 2024 and the ability to win the bid.

8. The bid development has to start now, because UEFA already will make the final selection of candidates in summer 2018.

9. Implementation of a part of objects can be started in advance even if the bid will be rejected. This approach will help to increase aggregate demand in Keynes's understanding and get the Baltic States out of recession.

This requires coordination at the political level. The host countries should give governmental warranties for such participation. Lithuania's chairmanship in the EU in 2013 gives a good opportunity of lobbying this project in the European Parliament, the European Commission and the Nordic Counsil of Ministers, in order to get targeted assistance in the construction of infrastructure projects in the Baltic States.

\section{Bibliography}

Aeschbacher, R. Euro 2008. Hohe Gewinne für die Uefa und Kosten für den Staat? Das Schweizer Parlament. Bern, 2008 [interactive]. [Retrieved 5 September, 2012]. <http:// www.parlament.ch/d/suche/seiten/geschaefte.aspx?gesch_id=20083442>.
Analogue systems. Cornwall, 2012. [interactive]. [Retrieved 5 December, 2012]. $<\mathrm{http}: / / \mathrm{www}$.analoguesystems.co.uk/ index $2 . \mathrm{htm}>$.

Chempionat Evropy po futbolu 2024 [European Football Championship 2024]. San Francis- 
co, 2012 [interactive]. [Retrieved 6 September, 2012]. <http://ru.wikipedia.org/wiki/ Чемпионат_Европы_по_футболу_2024>.

Coelho, I. Analogy. ACPI Encyclopedia of Philosophy. Bangalore: ATC. 1:64-68. Ed. Johnson J. Puthenpurackal, 2010.

IMF World Economic Outlook (WEO). Washington, D.C., 2012 [interactive]. [Retrieved 5 September, 2012] from $<$ http://www.imf.org/external/pubs/ft/ weo/2012/01/index.htm>.

Info-Guide of the Austrian Federal Chancellery. Sports Division and SpEA SportsEconAustria. Vienna, 2008. Issue No.3/May 2008 [interactive]. [Retrieved 5 September, 2012]. <http://www.esce.at/ speafile $/ 080523 \%$ 20UEFA $\% 20$ EURO $\% 20$ 2008\%20Datenvademecum\%20EN.pdf>.

Itkonen, E. Analogy as Structure and Process. Amsterdam/Philadelphia: John Benjamins Publishing Company, 2005.

Kolesnikov nazval stoimost kilometra ukrainskikh dorog [Kolesnikov called the cost of kilometer of the Ukrainian roads]. Kyiv, 2012 [interactive]. [Retrieved 5 September, 2012]. <http://gazeta. ua/ru/articles/business/_kolesnikovnazval-stoimost-kilometra-ukrainskihdorog/437284>.

Masterplan of Ministry of Sport and Tourism, State program for EURO 2012 preparation. Warsaw, 2012 [interactive]. [Retrieved 3 September, 2012]. <http://www.msport.gov. $\mathrm{pl} /$ przedsiewziecia-euro-2012>.

La France accueillera le championnat $d$ 'Europe de football en 2016. La France a remporté l'Euro 2016. Moscou, 2011. [interactive]. [Retrieved 3 August, 2012]. $<$ http://www.ambafrance-ru.org/La-Franceaccueillera-le>.

New high-speed Hyundai railway trains linked the host cities - Kiev, Lviv, Kharkiv and Donetsk. 24.05.2012. Vienna, 2012 [interactive]. [Retrieved 1 August, 2012]. $<\mathrm{http}: / /$ diepresse.com/>.

Polskie autostrady najdrozsze $w$ Europie. Warszawa, 2012 [interactive]. [Retrieved
10 September, 2012]. <http://www.drogi. inzynieria.com/cat/19/art/22034/analizakosztow-budowy-autostrad-w-europie-centralnej.html>

Polskie autostrady najdroższe w Europie. Warszawa, 2005 [interactive]. [Retrieved 10 September, 2012]. <www.bankier.pl/wiadomosc/Polskie-autostrady-najdrozsze-w-Europie-1248251.html>

Polska budowa dróg w latach 2007-2015. Warszawa, 2010 [interactive]. [Retrieved 28 August, 2012]. <http://www.transport.gov. pl/files/0/1793483/ projektProgramuBudowyDrgKrajowychnalata20112015.pdf $>$.

Poole, I. Cellular Communications Explained: From Basics to 3G. Oxford: Newness, 2006 Regional Economic Outlook. May 2011. Wasington D.C., 2011 [interactive]. [Retrieved 5 September, 2012]. <http://www.imf.org/ external/country/ukr/index.html $>$.

Portugalija - samaja zapadnaja strana Evropy. [Portugal - the most western country of Europe]. Moscow, 2007. [interactive] [Retrieved 7 September, 2012]. <http:// www.c.weare1.info/europe-portugal.html $>$.

Reformisty predlozhili provesty v. Estonii EVRO-2024. [Reformists suggested to carry out in Estonia EURO-2024.]. Tallinn, 2010. [interactive]. [Retrieved 20 August, 2012]. $<$ http://rus.postimees.ee/337081/reformistypredlozhili-provesti-v-jestonii-evro-2024/>.

Sivilevičius, H. Modelling the interaction of transport system elements. Transport (16484142). 2011, Vol. 26 Issue 1, p. 20-34.

Sowa, J.; Arun, K. Analogical reasoning. Conceptual Structures for Knowledge Creation and Communication, Proceedings of ICCS 2003. Berlin: Springer-Verlag, 2003. [interactive] [Retrieved 7 December, 2012]. <http://www.jfsowa.com/pubs/ analog.htm.,p.16-36>.

Sprawozdanie z realizacji przedsięwzięć Euro 2012 oraz $z$ wykonanych działan, dotyczacych realizacji przygotowań Polski do finalowego turnieju Mistrzostw Europy w Piłce Nożnej UEFA EURO 2012 TM (marzec 2011 r. - styczeń 2012 r.). 
Warszawa, 2012 [interactive]. [Retrieved 7 September, 2012] from <http://sejmometr. $\mathrm{pl} /$ projekt/445, dokument/46156,druknr-291>.

Strategy development of a transport industry of Ukraine, preparation to the EURO2012, investment potential. Kyiv, 2010. [interactive] [Retrieved 29 August, 2012]. $<$ http://mtu.gov.ua/article/show/article id/16568/highlight/euro+2012>.

Stadiums in Europe [interactive]. [Retrieved 6 September, 2012]. <http://www.worldstadiums.com/europe/maps/europe.shtml>.

The annual macro-economic database of the European Commission's Directorate General for Economic and Financial for nonEU countries. Brussels, 2012 [interactive] [Retrieved 3 September, 2012]. <http:// ec.europa.eu/economy_finance/db_indicators/ameco/index_en.htm>.
UEFA_Euro_2020_bids. San Francisco, 2012. [interactive]. [Retrieved 2 August, 2012]. $<$ http://en.wikipedia.org/wiki/UEFA_ Euro_2020_bids>.

UEFA Club Licensing and Financial Fair Play regulations. Nyon, 2009 [interactive]. [Retrieved 23 August, 2012]. <http://www.uefa. com/uefa/footballfirst/protectingthegame/ clublicensing/index.html>.

$V$ Ukraine stroitelstvo $1 \mathrm{~km}$ dorogi obkhoditsja $v 5 \$ \mathrm{mln}$. [In Ukraine construction of 1 km. roads costs \$5 million.] Kharkiv, 2011. [interactive] [Retrieved 7 September, 2012] from $<$ http://stroyobzor.ua/news/75338>.

2018 FIFA World CUP. Bid Evaluation Report: Russia. [interactive]. Zurich, 2010. [interactive] [Retrieved 24 August, 2012]. $<$ www.fifa.com $/ \mathrm{mm} /$ document $/$.../b5ruse. pdf $>$.

\title{
NACIONALINIO MASTO MAKROEKONOMINIŲ SPRENDIMŲ ANALOGINIS MODELIAVIMAS: AR BALTIJOS ŠALYS GALE்TŲ PARENGTI UEFA EURO 2024?
}

\author{
Viktoras Justickis, Nikolajus Markevičius \\ Mykolo Romerio universitetas, Lietuva
}

Santrauka. Stambiu makroekonominiu sprendimu priemimas - viena sunkiausiu problemu šiuolaikineje ekonomikoje. Dèl jos sudètingumo kiekvienas toks sprendimas daro itaka begaliniam skaičiui ekonomikos parametru, veiksniu, reǐ̌kiniu, ryšiu ir sukelia daugybę netiketu ir neretai žalingu pasekmiu.

Müsu nesugebejimas numatyti visas šias pasekmes susietas visu pirma su tuo, kad dar nesugebame sukurti sudètingus, daugelì tükstančiu šiuolaikinès nacionalinès ekonomikos parametru apimančius jos modelius. Sis nesugebejimas susietas tiek su dabartiniu mokslo apie ekonominius modelius (ekonometrijos) apribojimais, tiek su müsu žiniu apie dabartines ekonomikos veikima netobulumu.

Dèl to nepaisant greitos šiuolaikinès ekonomikos mokslo ir modeliavimo pažangos, mes esame dar labai toli nuo modeliu, atspindinčiu realu nacionalinès ekonomikos sudetinguma ir dèl to gebančiu numatyti priimamu makroekonominiu sprendimu pasekmes.

Straipsnyje siūloma laikina alternatyva tokiems modeliams, sudaranti galimybę jau dabar modeliuoti nacionalinę ekonomika tikslu numatyti stambaus makroekonominio sprendimo pasekmes. 
Pasiūlymo esmé - panaudoti vadinamajì analogini nacionalinés ekonomikos modeliavima.

Siekiant numatyti tam tikro makroekonominio sprendimo pasekmes, jiems numatyti parenkama kita šalis su imanomai panašia ekonomika, kurioje toks sprendimas jau buvo priimtas ir žinomos jo pasekmes.

Tokios įmanomai panašios ekonomikos panaudojimas analoginiam modeliavimui remtusi keturiomis prielaidomis.

1. „Panašumas sukuria panašuma" prielaida: kuo didesnis yra dvieju ekonomiku panašumas, tuo didesnis ir ju vidinis (nematomas, giluminis) panašumas.

2. „Panašumo, susieto su sprendimu, svarba“: kuo panašesnès ekonomikos sferos, kurias labiausiai liečia sprendimas, tuo daugiau pagrindo pasirinkti viena iš šiu ekonomiku kitai prognozuoti ir tuo labiau galima numatyti makroekonominio sprendimo pasekmes.

3. „Bendro branduolio“" prezumpcija: jeigu ekonomikos panašios, šç panašuma dar labiau padidina pamatiniai bruožai, kurie büdingi visoms šiuolaikinems rinkos ekonomikoms.

4. „Bendros erdvès" prezumpcija. Dvieju ekonomiku panašumas dar labiau padideja, jeigu jos yra bendroje (pvz., Europos) geografineje, kultürinejje, ekonomineje, politinejje ir pan. erdveje.

Straipsnyje nagrinejamas nacionalinio masto sprendimas del UEFO Euro 2024 varžybu organizavima Baltijos šalyse. Nagrinejamas Portugalijos (kuri jau organizavo tokias varžybas) ekonomikos panaudojimas kaip analogini modeli numatant tokio sprendimo pasekmes Baltijos šalyse.

Reikšminiai žodžiai: nacionalinio masto (makroekonominiai) sprendimai, makroekonominis modeliavimas, UEFA EURO 2024, Baltijos šalys, Suomija, futbolas, laisvoji rinka, valstybinis reguliavimas.

Viktoras Justickis, Mykolo Romerio universiteto Socialinès politikos fakulteto Psichologijos katedros profesorius. Mokslinių tyrimų kryptys: teisé, ekonomika, kriminologija, psichologija.

Viktoras Justickis, Mykolas Romeris University, Faculty of Social Policy, Institute of Psychology, Professor. Research interests: law, economics, criminology, psychology.

Nikolajus Markevičius, Mykolo Romerio universiteto Ekonomikos ir finansų valdymo fakulteto Ekonomikos katedros docentas. Mokslinių tyrimų kryptys: ekonomika, tarptautiniai ryšiai, ekonominė kultūra darant politinius sprendimus.

Nikolajus Markevičius, Mykolas Romeris University, Faculty of Economics and Finance Management, Institute of Economics and Business, Associate Professor. Research interest: economics, international relations, economic culture of making political decisions. 
